\title{
THE SHARIA-BASED UNDERSTANDING OF RELIGIOUS FREEDOM AND WOMEN'S RIGHTS IN CONFLICT WITH THE SECULAR CONSTITUTIONAL STATE
}

\author{
Christine Schirrmacher \\ Bonn University, Germany
}

\begin{abstract}
ABSTRAK: Area-area konflik yang berhubungan dengan kebebasan beragama dan hak-hak perempuan tidak memengaruhi mayoritas Muslim yang melakukan ibadahnya di Jerman, yang di dalam prosesnya, tidak bertentangan dengan negara konstitusional. Hal ini juga tidak ada hubungannya dengan para teolog yang mengambil pembenaran mereka dari Qur'an dan sumber-sumber normatif Islam lain mengenai kebebasan beragama yang komprehensif serta hak-hak setara untuk perempuan. Tetapi, hal ini menyangkut para akademisi berpengaruh yang menafsirkan norma dan perintah Islam sedemikian rupa sehingga konflik muncul dengan hukum negara sekuler konstitusional. Para akademisi ini mempertahankan pandangan bahwa hukum Syariah berlaku sebelum hukum negara sekuler konstitusional dan bersifat mengikat untuk semua orang Muslim.
\end{abstract}

Pada saat ini, pertanyaan mengenai kebebasan beragama dapat dimengerti sebagai topik yang secara virtual memiliki relevansi yang kecil di dalam konteks Eropa yang sangat sekuler dan netral terhadap agama. Sampai di manakah posisi inner-Islamik menjadi perhatian bagi negara konstitusional 
dalam hal kebebasan beragama? Bagi negara konstitusional, mengevaluasi agama dan doktrin bukanlah perhatiannya. Ini juga berlaku untuk agama Islam. Meskipun demikian, apabila suatu tindakan dibenarkan oleh keyakinan agama, atau dari apa yang mereka ikuti, atau dari apa yang dideklarasikan sebagai kewajiban menurut para pemimpin agama yang berpengaruh, dan di mana tindakan-tindakan ini melanggar hukum yang ada atau membatasi hak-hak dasar individu, maka negara dan perwakilannya harus memperhatikan keyakinankeyakinan ini, terlepas dari apakah keyakinan ini bersifat agamawi, politis, atau agamawi dan politis sekaligus.

KATA KUNCI: Jerman, Islam, kebebasan beragama, hak-hak perempuan, negara konstitusional, konflik

ABSTRACT: The areas of conflict relating to the freedom of religion and women's rights do not affect the majority of Muslims who practice their religion in Germany and, in the process, they do not clash with the constitutional state. This is also not a matter having to do with those theologians who take their justification for comprehensive religious freedom and equal rights for women from the Koran and, respectively, other normative sources of Islam. Rather, it has to do with those influential scholars who interpret the norms and commands of Islam in such a way that conflicts arise with the laws of a secular constitutional state. These scholars defend the view that the laws of the Sharia are prior to the norms of the secular constitutional state and are obligatory for all Muslims. 
At the present moment, the question of freedom of religion could be virtually understood as a topic which, in largely secularized Europe and for the religiously neutral state, possesses little relevance. To what extent do inner-Islamic standpoints interest the constitutional state on the question of religious freedom? For the constitutional state, it does not concern itself with the question of evaluating a religion and its doctrinal content. This also applies with respect to Islam. There, however, where actions are justified by religious convictions, or where they follow from them or are declared to be mandatory by influential religious opinion leaders, and where these actions infringe upon established law or limit the basic rights of individuals, the state and its representatives have to concern themselves with these convictions, independent of whether these convictions are of a religious, political, or of a religious and political nature.

KEYWORDS: Germany, Islam, freedom of religion, women's rights, the constitutional state, conflicts

\section{MIGRATION AND ISLAM}

There are over four million Muslims living in Germany and more than 15 million in all of Western Europe. And the figures are increasing. A significant part of the Muslim community views itself as believing and practicing, and a portion of those are very devout and practice their religion intensively. Over recent years, relevant studies have repeatedly confirmed that around $85-90 \%$ of the Muslims in Germany label 
themselves as rooted in the Islamic religion. ${ }^{1}$ Even if that does not mean that every individual holds to all commands and observes every detailed provision in his life, it still highlights the fact that Islam has remained a part of the identity of many Muslims in Europe into the third generation. During the first two generations of the Gastarbeiter (guest worker) immigration, it was mostly assumed that Islam would soon experience a secularization process in Europe. This assumption has in large part been shown to be false. The third generation of Muslim migrants is overall more strongly bound to Islam than the first generation was. Political Islam in Europe is nowadays distinctly more perceptible than it was 50 years ago - and this applies around the world.

We all know that Islam does not have a priesthood and also does not have a supreme teaching authority, above all not in the Sunni realm. Also for that reason, the understanding of what religion requires of people and what it obligates people to - not least in public, political, and in the social realms - is still strongly shaped by developments, movements, and personalities in the countries of origin. Whatever is preached there arrives here via book publications, satellite, and the

${ }^{1}$ For instance, a study by the German Federal Ministry of the Interior labels $85 \%$ of the Muslims in Germany as 'religious' or 'very religious': Katrin Brettfeld/Peter Wetzels, Muslime in Deutschland. Eine Studie des Bundesinnenministeriums zu Integration, Integrationsbarrieren, Religion und Einstellungen zu Demokratie, Rechtsstaat und politisch-religiös motivierter Gewalt. Ergebnisse von Befragungen im Rahmen einer multizentrischen Studie in städtischen Lebensräumen, Hamburg 2007, 138. 
Internet. And even if it is not every Muslim in Europe who orients himself towards these voices from their countries of origin, it seems to me that this fact is still crucial to understanding Islam in Europe. Up to the present day, we have still not seen the establishment of an independent European theological Islam which takes up essentially justifiable positions against the traditional Sharia-focused viewpoints of classical theology. With that said, there has been no ability demonstrated to principally reach consensus on deriving basic civil rights and liberties from the center of Islam for a libertarian and secular context.

\section{THE INFLUENCE OF NEAR EASTERN ISLAM ON EUROPE}

For this reason, there is no transfer of a European enlightened Islam into the Near and Middle East. On the contrary: Up to the present day, influential Islamic theologians, above all from core Arab countries, have had a significant impact on Islamic communities in Europe with their official statements. For example, I am thinking here of Yusuf alQaradawi (geb. 1926), who is well known to specialists. He is originally from Egypt and now lives in Qatar: $\mathrm{He}$ is a theologian who has written around 120 books, operates three of his own web pages, and is in the foreground on these sites as a prominent personality, ${ }^{2}$ has his own program on the Arab television station al-Jazeera and appears in part weekly on it,

${ }^{2}$ http://www.qaradawi.net, http://www.islamonline.net (in English and Arabic), and http://www.onislam.net. 
produces fatawa (legal opinions), takes a stand on issues, and repeatedly gives his opinion on political events: Just recently, on February 18, 2011, al-Qaradawi led Friday prayer on Tahrir Square in Cairo during the Arabellion. This achieved a great publicity effect. Furthermore, he conveyed his congratulatory wishes upon the occasion of the Egyptian Revolution which he viewed as God's punishment and as the inevitable triumph of believers over an oppressive pharaoh-like regime. ${ }^{3}$

The total number of al-Qaradawi's books which have been sold reach into the hundreds of thousands; of the books published, many have been translated into European, African, and Asian languages. Since the 1970s, he has been an advisor to various Islamic banks and financial institutions. ${ }^{4} \mathrm{He}$ is the founder and Chairman of His reach with the media the European fatwa council, which started in 1977. Its official name is the European Council for Fatwa and Research. He is the Chairman of the International Union of Muslim Scholars, which he co-founded in 2004, Chairman of the International Association of Muslim Scholars, founder of the Federation of Islamic Organisations in Europe (FIOE), which was started in

3 Yahya M. Michot. “Qaradawi's Tahrir Square Sermon: Text and Comments." http://www.onislam.net/ english/shariah/contemporaryissues/interviews-reviews-and-events/451341-the-tahrir-square-sermon-ofsheikh-al-qaradawi.html?Events= (accessed February 21, 2012).

${ }^{4}$ For a list of his positions in the financial sector see:

Ermete Mariani, Youssef Al-Qaradawi: "Pouvoir Médiatique, Économique et Symbolique" in: Frank Mermier (ed.), Mondialisation et nouveaux médias dans l'espace arabe, Maisonneuve \& Larose, Paris, 2003, 195203, here 201f. 
1989, and he is closely tied to the Egyptian Muslim Brotherhood. is so great that one would be correct to assume that al-Qaradawi is currently the most influential Sunni scholar. He not only passes on his knowledge at educational establishments in Qatar, where he has taught since the beginning of his time of exile in 1961. He also has links to the French educational establishment Château-Chinon, where European actors on the stage of political Islam are trained.

The position of the 86 year-old Yusuf al-Qaradawi is above all of interest for us on the question of how Muslims live their everyday lives in the diaspora, where they find themselves in a minority position. Towards which standards should they orient themselves? Do they have to implement the entire Sharia? Are they allowed to accept compromises in a non-Islamic environment? To what extent should they observe European law? Where does Sharia law have priority?

\section{ISLAMIC 'MINORITY RIGHTS' FOR MUSLIMS IN THE EUROPEAN DIASPORA}

What is special about al-Qaradawi is that as an advocate of a method of 'centrism' and 'moderation' ( Arabic: wasatiya und ictidal), he champions the idea that Muslims can or even should ${ }^{5}$ temporarily adapt to the applicable law in the diaspora when they are in a minority position. Thus, for this period of

${ }^{5}$ Comp. his comments on the concept of 'wasatiya' and 'ictidal' in his work figh al-jihad. dirasa muqarana li-ahkamihi wa-falsafatihi fi dau' al-qur'an wa's-sunna, Maktabat wahba: al-Qahira, 20091, Vol. 1, $29 \mathrm{ff}$. 
transition, they do not have to observe all the commands of Islam. In his writings, he warns against exaggeration, which is not considered to be in accord with Islam. He especially refers to Europe, where the state and society would not enable a complete implementation of Sharia law.

Yusuf al-Qaradaw is one of the most important advocates of this sort of 'minority rights.' This legal conception, which was discussed by representatives of Islamic theology as early as the beginning of the $1900 \mathrm{~s}^{6}{ }^{6}$ is based upon two foundational assumptions:

1. Islam is a global religion, which justifies a permanent stay in the diaspora.

2. The search for practical solutions according to the intentions of Islamic law (maqasid ash-sharia) is justified. Owing to this, it is allowed to interpret Islamic law according to the requirements of life in a non-Islamic society and to establish corresponding forms of relief. In this way, the choice of a life in the diaspora is made possible with the best fitting solution.

According to al-Qaradawi, among the preconditions for this conception of things is a Muslim minority which is conscious of its special identity, a minority that grows out of her passivity, and a minority that recognizes its task to reconfigure non-Islamic society. For that reason, from al-Qaradawi's point of view, the Sharia (God's law), as it is understood from his

${ }^{6}$ Sarah Albrecht, Islamisches Minderheitenrecht. Yusuf al-Qaradawis Konzept des figh al-aqalliyat, Ergon: Würzburg, 2010, $19 \mathrm{f}$. 
viewpoint, is not allowed to be given up by Muslims; instead, they are to be instructed in the commands of Islam. Furthermore, they are to belong to the elite in their societies through the particularly good training they receive and, through their role model status and their proclamation of Islam $\left(d a^{c} w a\right)$, aim at permeating society with the Sharia. ${ }^{7}$

\section{RELIGIOUS FREEDOM FROM THE VIEWPOINT OF A ‘CENTRIST AND MODERATE’ POSITION}

From al-Qaradawi's point of view, religious freedom, before all else, is the freedom for non-Muslims to accept Islam. Islam is to be proclaimed in Western societies without hindrance. From his standpoint, Muslims may for all intents and purposes entertain inner doubts about Islam. However, they should overcome them by entrusting themselves to versed scholars. According to al-Qaradawi, whoever doubts inwardly is not allowed to be dragged before Islamic courts. People are not to be prematurely suspected. However, religious freedom never gives the right to Muslims to turn away from Islam or to convert to another religion. It does not include the opportunity to become an atheist. Whoever leaves Islam, as unmistakably expressed by al-Qaradawi in his writings, ${ }^{8}$ has initiated war

7 Yusuf al-Qaradawi dedicated himself to the particular situation of Islamic minorities in non-Islamic societies in Articles, fatawas and in his work fi figh al-aqalliyat al-muslima. hayat al-muslimin wasat al-mujtama'at aluhra, al-Qahira: Dar ash-shuruq, 2001.

${ }^{8}$ See in part. his magnum opus on falling away from Islam jarimat ar-ridda wa-'uqubat al-murtadd fi-dau' al-qur'an wa-'s-sunna, Maktabat wahba: 
against God, his messenger Mohammed as well as the Islamic community and has to be subject to the death penalty. This is due to the fact that the Koran, tradition, and early Islamic scholars consistently taught the obligation to perform executions in such case, and this understanding is unambiguously anchored in the Sharia, God's law.

The goal of such minority law is not the integration of Muslim immigrants into European societies; instead, in the opposite sense, it obligates Muslims living in European societies who call up al-Qaradawi's programs, fatawa, and official statements on the internet or see them presented on television to be permanent 'others' in Europe. Indeed, for the time being they should temporarily accept European constitutional states. However, they should not ultimately acknowledge it. Rather, through instruction and the complete implementation of Islam, they should prepare for the coming time in which the situation will have been so changed that the educated and instructed avant-garde within the Islamic community, trained in the comprehensive form of Islam, will take over leadership. For that reason, it is not surprising that alQaradawi does not provide for equal rights for women and nonMuslims. He does not place the classical interpretation of Sharia law up for reconsideration at any point.

al-Qahira, 20053', as well as his late work, his jihad theology, carrying the title figh al-jihad. dirasa muqarana li-ahkamihi wa-falsafatihi fi-dau' al-qur'an wa-'ssunna, Maktabat wahba: al-Qahira, 200911, 169-192. 
Scholarly findings about al-Qaradawi should not be dismissed as the results of research in the ivory towers of Islamic scholarship. Even if al-Qaradawi is himself at home in the Far East and exclusively addresses the Muslim community in the Arabic language, he still exerts a strong influence on the diaspora community in Europe. As a believing community, this group seeks orientation and guidance in a non-Islamic, predominantly secular environment. However, orientation and guidance is hardly seen in statements by proponents of liberal or progressive Islam. A holistic form of Islam, which is comprehensive and reflects all aspects of social and political life, and which has instructions ready for every life situation, is primarily found with advocates of political Islam, such as in the case of al-Qaradawi. Owing to his great media effectiveness, via his publications, television programs, and internet presence, he shapes the understanding of individual believers as well as significant actors on the stage of political Islam in Germany. Muslims oriented in this direction are, for instance, instructed in Château-Chinon, thus in an educational establishment where al-Qaradawi participates in the formation of its orientation and teaching. No Islam compatible with democracy will come from there.

\section{THE INFLUENCE OF POLITICAL ISLAMIC OPINION LEADERS ON THE ISLAMIC COMMUNITY IN GERMANY}

Just which level of validity do statements such as alQaradawi's understanding of minority rights and religious freedom have? What do other actors on this stage say about this 
topic? Are there alternative points of view? Is al-Qaradawi's position not itself a minority position within the Islamic community?

One could naturally argue against engagement with alQaradawi by mentioning that he is a Salafist, even if he is a reformed Salafist. ${ }^{9}$ As a consequence, he belongs to one of the strands of Islam professing to be political and which would like to establish the Sharia on a global scale. He advocates suicide attacks, especially in Israel, as he views Israeli society to be a military society through and through ${ }^{10}$ where no one has to be spared. Indeed, he himself could imagine nothing greater at the end of his life than to blow himself up in a wheelchair in Israel. ${ }^{11}$ Why, then, does al-Qaradawi interest us?

${ }_{9}$ According to Sarah Albrecht, he views himself as belonging in the tradition of Salafiyya: Sarah Albrecht, Islamisches Minderheitenrecht. Yusuf alQaradawis Konzept des figh al-aqalliyat, Ergon: Würzburg, 2010, 40-1. However, al-Qaradawi also advocates rather untypical conceptions for the Salafiyya, for instance that singing and listening to music are permitted; at the same time, he labels his relationship to the Salafiyya as good: Huda al-Salih, "AlQaradawi: I Call for making Sufism into Salafi, and making Salafi into Sufi" in: Al-Sharq al-Awsat Online, Thursday, December 23, 2010, quoted in: "Shaykh Yusuf al-Qaradawi on Muslim Brotherhood, Salafi Tendency, Shiism, Women," http://www.biyokulule.com/view_content.php?articleid=3171 (accessed January 14, 2012).

${ }^{10}$ For instance, al-Qaradawi formulates it as follows in the fatawa "fi mafhum al-kufr wa-'l-kafir wa-mauqif minhu": "Die gesamte israelische Gesellschaft ist eine militärische Gemeinschaft": Yusuf al-Qaradawi, min hady al-islam. fatawa al-mu'asira, 4 Vols., Dar al-qalam li-n-nashr wa-'t-tauzi' bi-'1-Kuwait/al-Qåhira, 200911, Vol. 4, 790-7, here p. 795.

11 Comp. his talk at: 
As a Salafist, al-Qaradawi belongs to a minority, while the prevailing majority of Muslims in this country neither share his desire for a martyr's death in Israel nor do they call for the application of Sharia law, in particular in the penal code. They apparently do not have any difficulty with the existing principle of religious freedom. The Central Council of Muslims in Germany (Zentralrat der Muslime in Deutschland, or ZMD), for example, published an 'Islamic Charter' in 2002, a fundamental declaration of principle by Muslims in Germany on the relationship between Muslims, their state, and their society. ${ }^{12}$ In that document, the existing religious freedom in Germany is affirmed. Polygamy also does not appear to present a particular problem in Germany. Many Muslims expressly reject forced marriages and honor killings.

Will the positions such as those of al-Qaradawi on religious freedom and women's rights - in a moment I will speak more in detail about the topic of women's rights - survive on their own? Should we simply wait until perhaps the next generation of Muslims orient themselves less towards the role models from the Near East? Should we leave the question of when and to which extent women assert their emancipation to the women themselves and rather not interfere, as occasionally is called for? Will the problematic issue of such a politically oriented

http://www.youtube.com/watch?v=9YWAGhc2a-8 (accessed January 14, 2012). 14, 2012).

${ }^{12}$ Comp. the text at http://zentralrat.de/3035.php (accessed January 
Islam not just disappear on its own in time from a secularly oriented Europe? To put it pointedly: Aren't the security officials just overstating the problematic nature of voices such as al-Qaradawi? Is there not above all a theoretical question lurking in the words of warning about the incompatibility of such voices with libertarian and democratic principles? Are we speaking about a minority problem which in the next generation, or in the generation after that, at the latest, will take care of itself through the development of a liberal and enlightened Islam?

\section{VOICES OF POLITICAL ISLAM - ARE THEY JUST SIDE ISSUES?}

Unfortunately, it is not as simple as that. This is above all the case, despite all relativizing arguments, since the orientation European Muslims have toward the movements and personalities in their countries of origin remains strong. This becomes clear, for instance, when one looks at the online visits to the internet sites and the percentage of callers on alQaradawi's television programs. Muslims in Europe frequently inform themselves on the corresponding websites and allow everyday questions from the lives they lead to be answered on these forums: 'May my daughter ride a bicycle, or is it unfitting for her to be seen by men who are not relatives?' 'May I accept a son-in-law from a non-Islamic household if he converts to Islam?' ‘May I keep a dog?' ‘May my children accept sweets in 
the supermarket if they were possibly processed with pork fat?'13

Whoever looks for such forums on the Internet and reads the innumerable questions regarding every life situations in Western societies will no longer believe that we are dealing here with an irrelevant peripheral phenomenon of a few rigidly pious believers. For these people, because they consider this type of comprehensive implementation of Islam to be mandatory, it is a matter of fulfilling detailed instructions in a precise manner, also for the diaspora, in the form passed down to them from scholars such as al-Qaradawi. Furthermore, they want to orient themselves towards the directives of the Sharia, which was normatively set by authoritative legal scholars and theologians up to approximately the $10^{\text {th }}$ century.

With respect to religious freedom, from the time period mentioned there is a foundational determination made which has been accepted as practically unchallenged Sharia law in Sunni as well as in the Shiite realm: A change of religion, or the falling away from Islam is, from a Sharia point of view, considered to be high treason and a political offense which

${ }^{13}$ In Salah as-Sawi's position dated January 26, 2010, it is a question of whether girls are allowed to participate in sports or whether this is indecent. The question is essentially affirmed: Girls are permitted to participate in sports as long as their private parts are guarded and they wear the hijab:

http://www.islamonline.net/servlet/Satellite?cid=1262372444010\&pagename= IslamOnline-English-

Ask_Scholar\%2FFatwaE\%2F fatwaEAskTheScholar (accessed December 17, 2010). 
categorically has to be punished by inflicting the death penalty. ${ }^{14}$ There are also significant guidelines as to the legal status of women which are traceable back to period of time mentioned: According to Sharia law, for example, polygamy is essentially permitted. Scholars such as al-Qaradawi hold fast to this Sharia law from the early days of Islam and preach this to the Muslim community in Europe as the obligatory guideline, which at best could be set aside temporarily for reasons of practicality. That leads to conflicts with the system of a secular constitutional state.

Indeed, early Islamic Sharia law does not limit women in every aspect: There is no prohibition against women receiving an education; among the local conditions to be fulfilled is most often that the social norms of gender segregation and the good reputation of women have to be maintained. With respect to the duty to obey, which the wife has vis-à-vis her husband, Sharia law does not have an exception unless the husband demands

${ }_{14}$ Of course, scholars also advocate opinions which diverge but have been unable to achieve significant agreement among important scholars and overall have achieved little ability to assert themselves in the heart of Islamic theology. Thus, Abdullah Saeed, for instance, one of the most globally engages Muslim campaigners for human rights and civil rights and liberties, among others, substantiates complete religious freedom from the text of the Koran and tradition. He draws the conclusion that the death penalty set down in Sharia law as mandatory for converts, which was formulated in the early days of Islam owing to the political threats facing the Islamic community today no longer have any: Abdullah Saeed/Hassan Saeed, Freedom of Religion, Apostasy and Islam. Ashgate: Aldershot, 2004. 
something from the wife which is against Sharia law. Advocates of classical Sharia law also demand the unconditional veiling of women.

In light of the described dependencies the European Muslim community has on Near Eastern, predominantly traditional Sharia oriented theology, the religious scholars named are in particular also attempting to establish the mentioned Sharia legal norms in Europe as a characteristic of Islamic piety. The publications of these theologians, who are bound to the traditional understanding of the Sharia, are injected into the public area in a multitude of ways: They are offered in numerous mosques, propagated via regional and national conferences, and distributed on the Internet.

\section{WOMEN'S RIGHTS FROM THE VIEWPOINT OF POLITICAL ISLAM}

al-Qaradawi's best known publication, and perhaps the most widespread book ever by an Islamic theologian in Europe is al-Qaradawi's oft translated early work dating from 1960, The Lawful and the Prohibited in Islam (Arabic version: al-halal wa-'lharam fi 'l-Islam; German version: Erlaubtes und Verbotenes im Islam). ${ }^{15}$ The German version is also sold in mosques in

${ }^{15}$ Husam Tammam assumes that this work by al-Qaradawi has experienced 30 editions up to now and has appeared in over 20 languages: "Yusuf al-Qaradawi and the Muslim Brotherhood" in: Jakob SkovgaardPetersen/Bettina Gräf (eds.), Global Mufti. The Phenomenon of YusufalQaradawi, Hurst \& Company: London, 2009, 55-83, here p. 58. 
Germany.

In that book, al-Qaradawi not only - as is natural advocates the death penalty for falling away from Islam. ${ }^{16} \mathrm{He}$ also grants permission to strike one's wife and demand her unconditional obedience. The husband is authorized to issue directives to her. If she rebels against his authority, he should rebuke her. And if that does not help, then he may "beat her lightly with his hands, avoiding her face and other sensitive areas." 17

Whoever is shocked by this formulation - and correctly so - then it is recommended that one primarily study the Arabic original edition of al-Qaradawi's work The Lawful and the Prohibited in Islam, which I have examined in four Arabic editions from the years 1960 to1993. In each of these editions alQaradawi formulates it as follows:

And if this approach fails and that also [what is meant is the first stage of correction recommended in Sura 4:34 in the case of conflict, which is rebuke and sleeping apart from her], then the husband should try chastisement with his hand, flanked by strong (or: tormenting) blows, yet staying away from her face. According to the set degree of chastisement, this is the curative treatment

16 Yusuf al-Qaradawi, al-halal wa-'l-haram fi 'l-islam, Dar ihya' alkutub al-'arabiya, al-Qahira, 1960, 237.

17 According to the German translation of the book: Ahmad von Denffer (trans.), Jusuf al-Qaradawi. Erlaubtes und Verbotenes im Islam, SKD Bavaria: München, 1989, 175. 
which is effectual in many a case."18

At this point, al-Qaradawi recommends the chastisement of the wife "with heavy blows" in the case of disobedience - as the implementation of the instructions given in Sura 4:34 to husbands in order to break the resistance of wives in the case of disobedience. The translation of this book has allowed wide marital abuse to result from this instruction. al-Qaradawi has thrown his weight upon the scales and sees in the chastisement of a wife the implementation of a part of Islamic religious duties. al-Qaradawi is by far not the sole individual on the German mosque book market with such recommendations. And they are not only found in the case of Arab authors. For example, the Vakf1 Foundation (German: Vakf1-Stiftung ), which is associated with the Turkish DITIB, brought out a book in German carrying the title What is allowed and what is prohibited (German title: Erlaubtes und Verwehrtes): In that book a husband is awarded the right to chastise his wife by striking her when she is recalcitrant: Corporal chastisemen, depending upon the circumstances, is allowed as a final resort when other steps do not lead to success in the case of certain wives." 19

Such publications have been ignored for far too long. They influence the Islamic community, even if at the same time I would like to emphasize that many Muslims do not follow

18 The first edition, for instance: Yusuf al-Qaradawi, al-halal wa-' $l$ haram fi 'l-islam, Dar ihya' al-kutub al-'arabiya, al-Qahira, 1960, 145.

${ }^{19}$ Hayrettin Karaman, Erlaubtes und Verwehrtes, Translated from Turkish by H. Achmed Schmiede, Türkiye Diyanet Vakfi: Ankara, 1996², 117. 
these recommendations. Indeed, they expressly reject them. Nevertheless, such calls cannot be tolerated as expressions of religious freedom.

Neither the publications of the Vakf1 Foundation (German: Vakf1-Stiftung) nor al-Qaradawi's official statements regarding falling away from Islam and regarding the chastisement of disobedient wives are statements by militant jihadists or theological outsiders. Instead, they come from the center of Islamic theology: al-Qaradawi was educated at one of the largest and most influential educational establishments in the Near East, al-Azhar University in Cairo.

The problematic nature of such publications lies in the fact that they suggest the following alternative. Truly believing Muslims have to decide: between either a God-pleasing life ordered completely according to the Sharia (including the mentioned guidelines) or a Western style of life attributable to democracy. These scholars aggravate and inhibit integration by issuing sustained reminders to Muslim believers regarding Sharia law and by in part having quick condemnation at hand for unbelief in the case of hesitant and reluctant individuals.

\section{ISLAM AND DEMOCRACY - IN OPPOSITION TO EACH OTHER?}

A number of studies independent of each other and conducted over many years have shown that between $45 \%$ and $49 \%$ of all Muslims in Germany see a form of opposition 
between Islam and democracy. ${ }^{20}$ In a practical way they have come to terms with democracy and value its advantages. But how do we get this high number of almost $50 \%$ ?

This close to $50 \%$ is not to be counted as portion of the extremists or among the number of terrorists, but they are shaped by Islamist opinion leaders, such as al-Qaradawi. What is communicated to them by in part Islamist oriented scholars bound to tradition is that they have to decide between a comprehensively implemented faith and the enemy camp. If they advocate a more moderate Isalm and make cuts with respect to social implementation, they are condemned as traitors of Islam by scholars such as al-Qaradawi. At the same time, al-Qaradawi is neither a jihadist nor an extreme outsider but rather a traditionally educated theologian. When he appears in television programs, on the Internet, and in his publications, he does so with the bearing, language, and typical clothing of a scholar. He is regarded as the authority of Sunni Islam. He places his hearers, readers, and viewers before the choice of practicinig the entire Sharia or of falling away from Islam. If this message is followed, it leads to conflicts with the

${ }^{20}$ For instance, the study "Muslims in Germany" dating from 2007 identified the following numbers: " $46.7 \%$ 'rather' agreed or 'completely' agreed that following the commandments of my religion ... [are] more important for me than democracy": Katrin Brettfeld/Peter Wetzels, Muslime in Deutschland. Eine Studie des Bundesinnenministeriums zu Integration, Integrationsbarrieren, Religion und Einstellungen zu Demokratie, Rechtsstaat und politisch-religiös motivierter Gewalt. Ergebnisse von Befragungen im Rahmen einer multizentrischen Studie in städtischen Lebensräumen, op. cit., 141. 
foundations and laws of a constitutional state, e.g., with respect to religious freedom and women's rights.

The question of the role and self-understanding of traditional scholars in Arabic Countries nowadays is an interesting one. On the one hand, state law is for all practical purposes secular law; up to now, this has been the case in Egypt, for example. Sharia law does not have any meaning. In most countries neither are hands cut off as the punishment for theft nor are adulterers stoned (there are a number of exceptions, such as Saudi Arabia or the northern states of Nigeria). In most countries characterized by Islam, Sharia law has been pushed back to the area of civil law, as in Egypt, thus to areas of application such as marriage, divorce, child custody, and inheritance law.

On the one hand, especially from the onset of the $19^{\text {th }}$ century, scholars lost a great part of their earlier significance and were increasingly pushed to the margins when it came to the area of application of traditional law in the dispensation of justice. On the other hand, by their holding fast to the undiminished validity of Sharia law, they keep the public conscience continually awake by pointing out that the only sources for law and justice are the Koran and tradition, i.e., the role model of Mohammed and his first successors. Only on the basis of that can one recognize in the present day what an individual is allowed to do and what is not allowed. That is the line of interpretation of traditionally educated believers such as al-Qaradawi. Only the Koran and tradition apply for al-Qaradawi; human law has no authority. What did Mohammed practice? 
What did the first four caliphs decide? Only that has relevance. In the diaspora situation in which Muslim migrants find themselves, these traditionally educated scholars from the Near and Middle East have an effect in Germany. They continually maintain an awakened awareness of the opposition between God's law and democracy: The actual task and obligation of the believer lies in living according to the guidelines derived from the Koran and the sunna.

Many appear to expect a solution of this conflict to come from these influential and traditional scholars by their developing an enlightened Islam and by pushing through a liberalization of Islamic law. Such a case would lead a considerable number of critics, of progressives, of intellectuals, of human rights activists, of advocates of women's rights, and of critical Koranic scholars who have developed alternatives to this Sharia-centered view of religious duties to be able to express themselves more freely and allow a culture of critical discussion to develop within the Islamic community. If for a moment one disregards the critics, there are many Muslims who in everyday life do not deal with the mentioned problematic statements, and there are entire communities, such as the Alevis, who rejected the Sharia very early on. Corresponding to this view, politics should proclaim or even call for such an enlightenment of Sharia Islam and a liberalization of its items of faith for the benefit of peaceful coexistence in democracy.

One understanding which deviates from this sees a solution in driving religion out of the public sphere. With that 
said, a laical model is demanded. If less religion is allowed into the public sphere, then to a lesser extent and only at prominent points can legal infringements be prompted. In this way, the conflicts with a Sharia-centered Islam are minimized.

\section{THE NECESSITY OF A NEW MODEL FOR TEXTUAL INTERPRETATION}

But do these suggestions lead to a promising solution? My thesis is: Neither the demand on the part of the enlightened nor the hope for a practical suspension of the Sharia in the coming generations nor pushing religion out of the public sphere can supplant the confrontation with the ideological roots of political Islam and, more specifically, Sharia Islam. Only promoting those who are enlightened or attempting to establish religiousfree zones will not enable us to dodge this ideological confrontation, which has to be conducted with all resoluteness.

Naturally there are important and sensible steps in the calls made by intellectual critics, humans rights and women's rights activists, progressives, those who are enlightened as well as in the inclusion of all democratically inclined Muslims. Yet, they do not replace a spirited confrontation with the positions held by traditionally educated scholars which collide with the essential principles of a secular constitutional state and, for that reason, cannot claim legitimacy for themselves. This contentbased confrontation with the roots, the argumentation, and the consequences of the teachings of a Sharia-oriented Islam is absolutely necessary. By invoking the Koran and the sunna, by invoking an alleged ideal early time of Islam with Mohammed 
as the field commander, lawgiver, and herald rolled into one, the advocates of political Islam want to justify their declared objective, return to this early time of Islam, and unite religion and state rule along with Sharia law under one roof.

With respect to the way towards acceptance and assertion of a form of Islam compatible with democracy and basic civil rights and liberties, there is a problem which has not been solved up to now. It is the question of an acknowledged method of interpretation and appraisal of the central historical Muslim texts. Indeed, there have been various Muslim individuals, for instance Abdullahi an-Na'im ${ }^{21}$ or Abdullah Saeed, ${ }^{22}$ who have developed models of Islam which are reconcilable with human rights and, in particular, with the equal rights of women, minority rights, and religious freedom. However, the essential question of a method to effectively defuse Islam as a legal system has remained with us up to this time.

Abdullah Saeed, born in 1960 in the Maldives, and he received a markedly conservative education in Pakistan and in Saudi Arabia. He teaches in Australia and has published a series of books and articles in which he speaks out unreservedly for religious freedom, for women's rights, and for equal rights. ${ }^{23}$

${ }^{21}$ See, for instance, his arguably most important work: Abdullahi Ahmed An-Na'im, Towards an Islamic Reformation. Civil Liberties, Human Rights, and International Law, Syracuse University Press: New York, 1990.

22 See, for instance, the article: Abdullah Saeed, "Reading the Quran" in: Amyn B. Sajoo (ed.), A Companion to the Muslim World, I. B. Tauris Publishers: London, 2009, 55-85. 
Abdullah Saeed maintains that many of the items found in tradition about what Mohammed and the first Muslims were supposed to have said and done are unreliable. As far as he is concerned, the Koran and what can be attributed to contemporary witnesses of Mohammed are the only things which count. From his viewpoint. later accounts do not count. In his opinion, the required political regulations at that time cannot be taken at face value and transferred as applicable to present-day circumstances. ${ }^{24}$ Abdullah Saeed has his own method in which the political sections of the Sharia are attenuated. Furthermore, in the case of the execution of apostates, for example, he sees it as entiely suspended.

Abdullahi An-Na'im (b. 1946 in Sudan) sees himself as a reformer of Islam and denies the political parts of the Sharia (e.g., also capital punishment). As far as he is concerned, Medinan Islam, i.e., the time when Mohammed was also a

23 See, for instance: Abdullah Saeed, "A Fresh Look at Freedom of Belief in Islam" in: Damien Kingsbury/Greg Barton (eds.), Difference and Tolerance. Human Rights Issues in Southeast Asia. Deakin University Press: Geelong, 1994, pp. 27-37, accessible at http://apostasyandislam.blogspot.com (April 13, 2010), as well as: Abdullah Saeed, "Creating a Culture of Human Rights from a Muslim Perspective" in: Swee-Hin Toh/Virginia F. Cawagas (eds.), Proceedings of the International Symposium Cultivating Wisdom, Harvesting Peace. Education for a Culture of Peace through Values, Virtues, and Spirituality of Diverse Cultures, Faiths, and Civilizations, Multi-Faith Centre, Griffith University: Brisbane, 2006, 123-7, http://www.abdullahsaeed.org/articles (accessed May 20, 2011).

${ }^{24}$ Abdullah Saeed, "A Fresh Look at Freedom of Belief in Islam" in: Damien Kingsbury/Greg Barton (Hrsg.). Difference and Tolerance. Human Rigths Issues in Southeast Asia, Deakin University Press: Geelong, 1994, 27-37. 
lawgiver and a field commander, is only history. Otherwise, there is not way to have peace between a liberal society and Islam. ${ }^{25}$ Abdullahi An-Na'im thus pursues another method. In order to de-politicize Islam, he distinguishes between Meccan and Medinan Islam, between early Islam and late Islam.

Even if numerous Muslim intellectuals, theologians as well as human rights and women's rights activists deny Sharia Islam, with all its problematic positions - in other words, corporal punishment, disdain for and legal disadvantaging of other religions and their representatives, denial of complete religious freedom as well as the desire for permeating society with political principles of the Sharia: They have developed their own method of textual judgment, but not one of them is publicly taught or discussed. Instead, they are for the most part ignored at the established institutes of learning. For that reason, these alternative blueprints have not had any broad impact up to the present time. Instead, what hovers over all of these scholars, intellectuals, and human rights activists is a verdict of heresy, of falling away from Islam. Unfortunately, they have not been able to speak out from the vantage point of the center of the Islamic community; rather, they are only able to speak from the margins. And they are pushed to the margins by the power

25 See, for instance: Abdullahi Ahmed An-Na'im, “Islamic Foundations of Religious Human Rights" in: Johan D. Van der Vyver/John Jr. Witte (eds.), Religious Human Rights in Global Perspective. Religious Perspectives. Martinus Nijhoff Publishers: Den Haag, 1996, pp. 337-59, as well as: Abdullahi Ahmed An-Na'im, Islam and the Secular State. Negotiating the Future of Shari'a, Harvard University Press: Cambridge, 2008. 
elite of established theology.

\section{WAYS TO RECONCILE WITH THE SECULAR CONSTITUTIONAL STATE}

In my opinion, the only way to come to a convincing reconciliation between an Islam oriented toward the Sharia and a democratic constitutional state is if from the center of Islamic theology, justification for two points can be found: for the rights of others - of those who think differently, of minorities which do not represent their own Islamic position - and for an abdication of power, abdicating the desire to configure society and politics according to the Sharia.

Historically, there have been approaches of such a type of Koranic hermeneutic, but these approaches have perished or have been marginalized. Because the methods of textual interpretation were stipulated from the beginning of the $10^{\text {th }}$ century, it is not as simple as presenting alternative models of interpreting the Koran in order to unhinge Islam's rootedness in history, whereby it is viewed as a steadfast and valid unity of society and politics. There cannot be any true reconciliation between traditional Islam and democracy until mainstream Islam, i.e., the established scholars from Egypt, Saudi Arabia, and Iran, are able to develop a new method of dealing with the sociopolitical elements of traditional Islam so that it is compatible with democracy and a secular constitutional state.

Only then would almost 50\% of the Muslims in Germany no longer have the feeling of having to decide between faith and democracy. This can only happen when established Islam 
and its proponents dispense with a claim to power, politics, and of wanting to configure politics and society according to a 'law of God.' This can only happen when theologians no longer condemn an apostate to death and no longer recommend that a husband strike his disobedient wife. This can only happen when non-Muslims in a state characterized by Islam are no longer second class citizens with reduced rights, and a liberal society with equally free citizens is able to come into existence there. As long as the established theology holds fast to conventional Sharia law as God's law for society, there can be no true emancipation for those who think differently, for women, minorities, intellectual critics, or converts. Moreover, there can be no equal freedom in societies characterized by Islam until fresh ground is broken. This will only happen when the Islamic society of the $7^{\text {th }}$ century A. D. and the circumstances projected into it are no longer made to be the measure of all things for the present.

It is not a liberalization of theology which is the solution. Rather, it is a new orientation of textual hermeneutics so that out of the center of theology and Islamic scholarship these basic civil rights have positive justification and can be defended. Then the representatives of the secular constitutional state will no longer have to concern themselves with the matters of faith of this religion. As long as this does not happen, the constitutional state has to critically check among proponents for attitudes and actions footing with such a political understanding of Islam to see to which extent they are compatible with democracy and fundamental rights. 
The state has to deal with the ramifications of Islamic, religiously motivated power claims in the state and society. The task to be taken up in established Islamic theology is the following: In order to accept comprehensive human rights and women's rights as well as to accept religious freedom in a positive manner, a surrender of the traditional worldly claim to power as defended in Islam up to now has to be theologically worked out, substantiated, and advocated. 